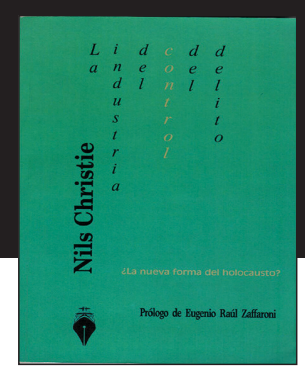

Nils Christie.

\title{
LIBROS
}

"LA INDUSTRIA DEL CONTROL

DEL DELITO. ¿La nueva forma

del Holocausto?"

Editores del Puerto SRL

220 páginas. Año 2007

\section{“LA INDUSTRIA DEL CONTROL DEL DELITO. ¿La nueva forma del Holocausto?}

Los controles sobre el delito, poco a poco tienden a globalizarse, el autor hace un recorrido por las concepciones mundiales, con énfasis en las europeas y nórdicas, y un breve repaso del pensamiento ruso y chino, para llegar al punto medular de la obra: la industria del control de delito en Estados Unidos y su influencia.

Este control al que refiere lo focaliza en las penitenciarías, bajo dos enunciados: ¿Hay esfuerzos por controlar la cantidad de delincuentes en las prisiones? ¿De qué depende esta cantidad? La política de seguridad nórdica está en contra de construir más cárceles; mientras que Estados Unidos incrementa cada día y rompe la sintonía de los países industrializados, donde el Estado puede ceder poder, concesionar funciones, ahorrar y generar empleo con la privatización de la administración, control y prestación de servicios de las penitenciarías y seguridad.

Christie desarrolla un cuestionamiento sobre lo ético, sobre si la concesión del Estado le hace perder poder, y si es legítimo que la sociedad acepte. En este recorrido se visualiza el enorme contraste entre el manejo de las superpotencias de sus problemas delictivos, y su sistema de ejercer justicia sin mucho margen a la discreción judicial, además de una cultura de marketing, donde todo se vende, todo se compra.

"La industria del control del delito" está dividido en doce capítulos donde sistemáticamente despliega su tesis de cómo se desarrolla este fenómeno concreto, que predice será abrazado mundialmente, y del cual tampoco ignora que en el devenir histórico ya tuvo modalidades en otras realidades y tiempos, como los campos de trabajos forzados en la extinta URSS que eran de enorme importancia para la economía soviética, generando millonarios ingresos. En la actualidad la guerra contra la delincuencia, anima y justifica toda inversión en materia de seguridad, el hacinamiento sugiere más infraestructura, más servicios, eficiencia, tecnología y por qué no, también armas. El imaginario de esta guerra es uno de los fuertes motores del desarrollo de la industria del control del delito.

Sinopsis a cargo de Leopoldo Wauthion Rivera Inspector de la Policía Nacional Civil El Salvador 